\title{
KHAZANAH EKOLEKSIKON KEDANAUAN DALAM GUYUB TUTUR BAHASA BATAK TOBA
}

\author{
Johandi Sinaga \\ Universitas Udayana \\ johansinaga1993@gmail.com \\ I Wayan Simpen \\ Universitas Udayana \\ wyn_simpen@unud.ac.id \\ Made Sri Satyawati \\ Universitas Udayana \\ srisatyawati@unud.ac.id
}

\begin{abstract}
ABSTRAK
Penelitian ini bertujuan mendeskripsikan khazanah ekoleksikon yang merepresentasikan lingkup kedanauan Danau Toba. Teori ekolinguistik digunakan dalam kajian ini. Data dalam penelitian ini adalah leksikon-leksikon yang berkaitan dengan lingkup kedanauan. Metode pengumpulan data yang digunakan adalah metode wawancara dan observasi. Dalam analisis digunakan metode deskriptif kualitatif. Hasil penelitian mengungkapkan 29 leksikon yang berkaitan dengan lingkungan kedanauan dengan tiga kategori entitas ekoleksikon yaitu ekoleksikon flora, ekoleksikon fauna dan ekoleksikon alat tangkap ikan. Kategori leksikon terdiri atas nomina dan verba. Bentuk-bentuk leksikon ada yang berbentuk dasar, bentuk turunan berupa kata ulang, dan kata majemuk.
\end{abstract}

Kata kunci: Alat Tangkap Ikan; Danau Toba; Ekoleksikon; Fauna; Flora

\begin{abstract}
This study aims to describe the ecolexicon treasures which represent the scope of Lake Toba. Ecolinguistic theory is used in this study. The data in this study are lexicons related to the scope of siltation. Data collection methods used are interview and observation methods. In the analysis used a qualitative descriptive method. The results revealed 29 lexicon related to the silt environment with three categories of ecolexicon entities namely flora ecolexicon, fauna ecolexicon and fishing gear ecolexicon. The lexicon category consists of nouns and verbs. There are lexicon forms that are basic, derivative forms in the form of repeated words, and compound words.
\end{abstract}

Keywords: Fishing Gear; Lake Toba; Ekoleksikon; Fauna; Flora

\section{PENDAHULUAN}

Bahasa adalah kekayaan budaya manusia. Salah satu fungsi bahasa dalam kehidupan manusia adalah mengembangkan akal budi manusia yang diperoleh dari interaksi dengan lingkungan sekitarnya yaitu sesama antar manusia dan antar makhluk hidup lainnya (Sudaryanto, 2017: 36). Entitas dalam suatu lingkungan ditandai dengan bahasa untuk membedakan satu dengan yang lain. Misalnya dalam lingkup kedanauan ada beragam entitas yang diwujudkan dalam bahasa dengan bentuk dan makna yang berbeda seperti leksikon dekke 'ikan', limut 'lumut' batu 'batu' rihit 'pasir' Seluruh entitas ini dibedakan dari bentuk dan maknanya. Pembedaan ini juga berfungsi untuk 
mempermudah kehidupan manusia mengenal dan berinteraksi dengan lingkungannya.

Manusia yang hidup dalam suatu lingkungan tertentu pasti lebih mengenal sampai mendalam entitas-entitas tertentu yang dekat dengannya dan ditandai sesuai dengan bahasa yang dituturkan. Seperti halnya di lingkungan hunian Danau Toba yang dihuni masyarakat Batak Toba, mengenal entitasentitas dalam lingkup danau itu dan mengkodekan atau memberi nama dengan bahasa yang dimiliki masyarakat setempat yaitu dalam bahasa Batak Toba.

Ekolinguistik merupakan ilmu bahasa yang mengkaji hubungan antara bahasa dan lingkungan (Mbete, 2009: 1). Kajian ini tidak lepas dari kerangka teori adanya interaksi, interelasi dan interdependensi antara bahasa dengan lingkungan yang membentuk suatu sistem bahasa sebagai tanda relasi yang saling timbal balik, keterhubungan dan ketergantungan dengan lingkungan. Dengan kata lain bahasa hidup karena lingkungan yang mendukung keberadaan bahasa,. (Fill, 2001: 43).

Lingkungan yang mengalami perubahan akan berdampak terhadap bahasa. Bertahan atau hilangnya suatu bahasa dipengaruhi oleh lingkungan yang menunjang eksisnya bahasa. Dalam bahasa Batak Toba yang berkaitan dengan lingkup kedanauan misalnya untuk alat tangkap ikan seperti, solu, hole, doton, adalah bahasa yang masih eksis dalam percakapan sehari-hari karena entitas bendanya masih banyak dan mudah ditemukan, beda halnya dengan sulangat, parippit, tahop yang sudah jarang digunakan dalam percakapan seharihari.

Berdasarkan latar belakang adanya permasalahan yang membutuhkan kajian untuk mendokumentasikan bahasa tentang ekologi lingkungan sangat penting dilakukan karena lingkungan fisik yang cenderung selalu berubah karena arus perkembangan zaman yang mendestruktif lingkungan dan menyebabkan hilangnya suatu bahasa. Pendokumentasian bahasa juga merupakan salah satu cara menyimpan kekayaan pengetahuan manusia yang tertuang di dalam bahasa.

Teori linguistik yang digunakan untuk mengidentifikasi bentuk-bentuk bahasa adalah teori morfologi. Morfologi sebagai cabang linguistik yang mengindetifikasi satuan-satuan dasar bahasa sebagai satuan gramatikal (Verhaar. J. W. M, 2008: 97). Kelas kata dibedakan menjadi sebelas macam yaitu nomina, verba, adjektiva, adverbial, pronominal, numeralia, preposisi, konjungsi, artikular, interjeksi, dan partikel (Chaer, 2008).

Penelitian terhadap objek Danau Toba juga sudah dilakukan oleh Charles (2017) yang meneliti tentang "Bahasa Kedanauan Kajian Ekolinguistik Tentang Pelestarian Ekosistem Danau Toba" tujuannya penelitian adalah medeskripsikan hasil investigasi, merekonstruksi, serta menganalisis cerita rakyat yang terdapat di lingkungan Danau Toba dengan pendekatan ekolinguistik untuk mengetahui sejauh mana cerita rakyat hidup dan menjaga keseimbangan alam (Butar-Butar, 2017).

Selain itu penelitian tentang objek kedanauan juga dilakukan oleh Sukhrani (2010) yang meneliti "Leksikon Nomina Bahasa Gayo dalam Lingkungan Kedanauan Lut Tawar: Kajian Ekolinguistik". Penelitiannya bertujuan untuk mengetahui pemahaman leksikon guyub tutur bahasa Gayo yang berhubungan dengan lingkungan ragawi Danau Lut Tawar, perangkat leksikon nomina menyangkut lingkungan ragawi Danau Lut Tawar dan dinamika lingkungan budaya kedanauan, kebertahanan, dan pergeseran leksikon bahasa Gayo di lingkungan Danau Lut Tawar (Sukhrani, 2010).

Penelitian ini mengkaji dan mendeskripsikan khzanah leksikon-leksikon apa sajakah yang berkaitan dengan flora, fauna dan alat tangkap ikan yang ada di Danau Toba serta mengidetinfikasi bentuk dan kaegorti leksikon kedanauan Danau Toba.

\section{METODE}

Data yang digunakan dalam penelitian adalah sejumlah leksikon yang berkaitan dengan flora, fauna dan alat tangkap ikan di Danau Toba yang terdiri dari kategori nomina dan verba. Teknik pengumpulan data dilakukan dengan cara observasi dan wawancara dengan masyarakat yang tinggal di kabupaten Samosir. Data yang yang diperoleh kemudian dianalisis menggunakan metode padan yang merujuk pada (Sudaryanto, 2015: 25) yaitu metode analisis bahasa yang alat penentunya berada di 
luar, terlepas dan tidak menjadi bagian dari bahasa yang bersangkutan, menggunakan teknik PUP yaitu teknik pilah unsur dengan yaitu daya pilah yang bersifat mental yang dimiliki oleh peneliti. Hasil analisis data dipaparkan dengan menggunakan metode kualitatif deskriptif yaitu memaparkan sejumlah temuan leksikon-leksikon yang berkaitan dengan flora, fauna dan alat tangkap ikan di Danau Toba.

\section{PEMBAHASAN}

Leksikon yang ditemukan yang berkaitan dengan lingkungan kedanauan dibedakan menjadi tiga kategori entitas ekoleksikon diantaranya adalah alat tangkap ikan, fauna dan flora dengan kategori nomina dan verba. Leksikon kategori nomina merupakan sejumlah kata yang merujuk pada benda atau entitas yang digunakan untuk menangkap ikan, fauna dan flora di Danau Toba, sedangkan kategori verba merupakan sejumlah leksikon yang berkaitan dengan kegiatan seperti menangkap ikan dan aktivitas lain yang dilakukan di Danau Toba.

\section{Bentuk Kebahasaan dan Kategori Ekoleksikon Flora \\ Leksikon dalam tabel berikut ini} merupakan leksikon yang berkaitan dengan flora yang ada dan hidup di lingkungan Danau Toba.

\begin{tabular}{llll}
\hline No & $\begin{array}{l}\text { Ekoleksikon } \\
\text { Kedanauan }\end{array}$ & $\begin{array}{l}\text { Makna } \\
\text { Dalam } \\
\text { Bahasa } \\
\text { Indonesia }\end{array}$ & $\begin{array}{l}\text { Kategori } \\
\text { Morfologi }\end{array}$ \\
\hline 1 & Teratai & Teratai & $\begin{array}{l}\text { Kata } \\
\text { Dasar }\end{array}$ \\
\hline 2 & Gambo & $\begin{array}{l}\text { Enceng } \\
\text { Gondok }\end{array}$ & Kata \\
& Dasar \\
\hline 3 & Limut & Lumut & Kata \\
& & Batu & Dasar \\
\hline 4 & Limut & Lumut & Bentuk \\
& Manjang & Majemuk \\
\hline
\end{tabular}

Berikut ini adalah beberapa gambar tumbuhan yang hidup di perairan Danau Toba.

\section{Gambar 1}

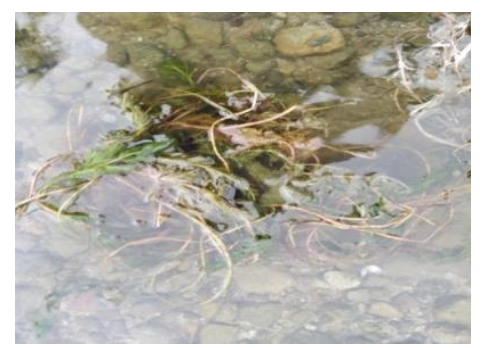

Limut Marihur

Sumber foto: Dokumentasi Johandi 2019

Gambar 2

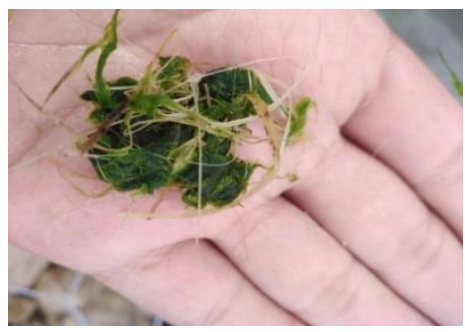

Limut Batu

Sumber foto: Dokumentasi Johandi 2019

Gambar 3

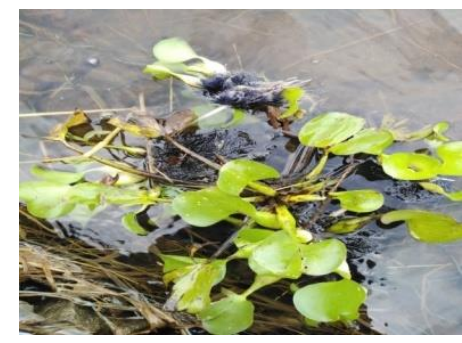

\section{Gambo}

Sumber foto: Dokumentasi Johandi 2019

\section{Ekoleksikon Flora}

Danau Toba kaya akan beragam jenis flora dan fauna yang turut menjadi penopang kehidupan yang berada di sekitarnya. Kehidupan berbagai jenis tumbuhan, hewan bahkan manusia di Danau Toba merupakan bentuk saling bergantung satu sama dengan yang lain. Tumbuhan yang hidup di Danau Toba dikelompokkan menjadi 2 yaitu tenggelam dan terapung. Entitas tumbuhan yang hidup di perairan Danau Toba ini juga dinamai menggunakan bahasa daerah Batak 
Toba. Tumbuhan terapung dikenal dengan leksikon bunga teratai dan gambo. Tumbuhan ini merupakan tempat ikan berlindung dari ikan buas dan juga tempat ikan menempelkan telurnya. Leksikon lain seperti Limut, limut marihur, limut sibolang merupakan jenis tumbuhan tenggelam dan juga sebagai tempat ikan berkembang biak. Selain itu fungsi dari tumbuhan yang ada di Danau Toba yaitu sebagai aerator melalui proses fotosintesis sehingga ikan dapat berkembang biak dengan baik. Selain itu tumbuhan air ini juga dimanfaatkan masyrakat sekitar seperti limut marihur yang digunakan sebagai pakan ternak. Begitu juga dengan gambo digunakan sebagai bahan kerajinan untuk dijual sehingga menambah nilai ekonomis masyarakat.

Keberadaan tumbuhan di Danau Toba menjadi salah satu faktor penentu keberlanjutan kehidupan makhluk hidup lain disekitarnya. Bentuk kerusakan yang terjadi seperti pencemaran air mengibatkan kerusakan berbagai tumbuhan yang akan menganggu ekosistem.

\section{Bentuk Kebahasaan dan Kategori Ekoleksikon Fauna}

Leksikon dalam tabel berikut merupakan leksikon fauna yang hidup di perairan Danau Toba dengan beragam jenis dan bentuknya.

\begin{tabular}{llll}
\hline No & $\begin{array}{l}\text { Ekoleksikon } \\
\text { Kedanauan }\end{array}$ & $\begin{array}{l}\text { Makna } \\
\text { Dalam } \\
\text { Bahasa } \\
\text { Indonesia }\end{array}$ & $\begin{array}{l}\text { Kategori } \\
\text { Morfologi }\end{array}$ \\
\hline 1 & Paetan & Ikan Sepat & Kata Dasar \\
\hline 2 & Mujahir & $\begin{array}{l}\text { Ikan } \\
\text { Mujahir }\end{array}$ & Kata Dasar \\
\hline 3 & Ihan & $\begin{array}{l}\text { Ikan } \\
\text { semah }\end{array}$ & Kata Dasar \\
\hline 4 & Nila & Ikan Nila & Kata Dasar \\
\hline 5 & Pora-pora & $\begin{array}{l}\text { Ikan } \\
\text { Bilis }\end{array}$ & Kata Ulang \\
\hline
\end{tabular}

Berikut ini adalah beberapa gambar fauna yang hidup di perairan Danau Toba.

\section{Gambar 4}

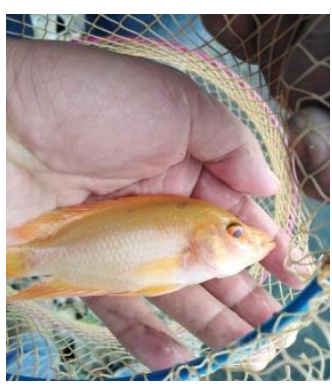

Nila

Sumber foto: Dokumentasi Johandi 2019

\section{Gambar 5}

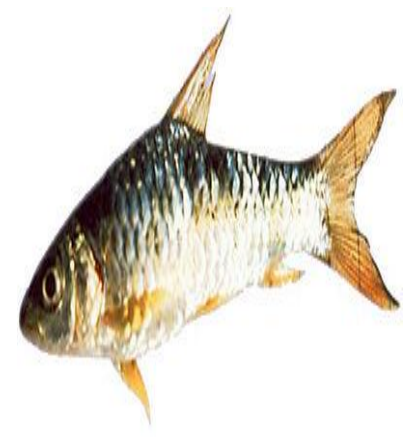

Ihan

Sumber Foto: Wikipedia diakses pada mei2020

\section{Gambar 6}

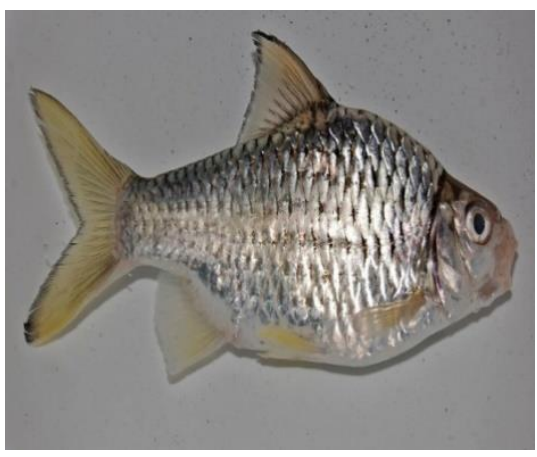

\section{Pora-pora}

Sumber Foto: Wikipedia diakses pada mei2020

\section{Ekoleksikon Fauna}

Danau Toba menjadi habitat berbagai jenis fauna seperti ikan. Masyarakat sekitar Danau Toba menamai jenis ikan dengan menggunakan 
bahasa Batak Toba. Leksikon seperti mujahir, nila dan pora-pora merupakan penanda namanama ikan yang hidup dan ditemukan di Danau Toba. Ikan menjadi salah satu sumber nutrisi hewani yang dimiliki masyarakat yang tinggal di sekitaran Danau Toba. Demikian halnya dengan leksikon paetan yang dikenal dengan sebutan ikan yang rasanya pahit oleh masyarakat. Ikan ini memiliki banyak tulang pada bagian dagingnya dan tidak menjadi pilihan untuk dikonsumsi oleh masyarakat. Leksikon ihan dikenal masyarakat dengan ikan yang sakral. Ikan ini hanya dikonsumsi untuk perayaan adat saja. Jumlahnya yang sedikit dan sulit ditemukan membuat harga ikan ini juga cukup mahal. Salah satu ikan yang sudah jarang ditemukan adalah ikan pora-pora.

\section{Bentuk Kebahasaan dan Kategori Ekoleksikon Alat Tangkap Ikan}

Leksikon dalam tabel berikut ini merupakan leksikon yang berkaitan dengan alat tangkap ikan. Alat ini merupakan benda digunakan oleh masyarakat Batak Toba untuk menangkap ikan di Danau Toba.

\begin{tabular}{|c|c|c|c|}
\hline No & $\begin{array}{l}\text { Ekoleksikon } \\
\text { Kedanauan }\end{array}$ & $\begin{array}{l}\text { Makna } \\
\text { Dalam } \\
\text { Bahasa } \\
\text { Indonesia }\end{array}$ & $\begin{array}{l}\text { Kategori } \\
\text { Morfologi }\end{array}$ \\
\hline 1 & $B u b u$ & $\begin{array}{l}\text { Tempat } \\
\text { penyimpa } \\
\text { nan ikan }\end{array}$ & $\begin{array}{l}\text { Bentuk } \\
\text { dasar }\end{array}$ \\
\hline 2 & Doton & $\begin{array}{l}\text { Jaring } \\
\text { ikan }\end{array}$ & Kata dasar \\
\hline 3 & Gobuk & $\begin{array}{l}\text { Alat } \\
\text { menakuti } \\
\text { ikan }\end{array}$ & Kata dasar \\
\hline 4 & Goli goli & $\begin{array}{l}\text { Tempat } \\
\text { duduk di } \\
\text { sampan }\end{array}$ & $\begin{array}{l}\text { Bentuk } \\
\text { Ulang }\end{array}$ \\
\hline 5 & Hole & $\begin{array}{l}\text { Dayung } \\
\text { sampan }\end{array}$ & Kata dasar \\
\hline 6 & Holom & $\begin{array}{l}\text { Pemberat } \\
\text { jaring ikan }\end{array}$ & Kata dasar \\
\hline 7 & Oddor & $\begin{array}{l}\text { Alat } \\
\text { pancing }\end{array}$ & Kata dasar \\
\hline 8 & Rambang & $\begin{array}{l}\text { Jala } \\
\text { panjang }\end{array}$ & Kata dasar \\
\hline 9 & Sidua tali & $\begin{array}{l}\text { Alat } \\
\text { pancing }\end{array}$ & $\begin{array}{l}\text { Bentuk } \\
\text { Ulang }\end{array}$ \\
\hline 10 & Jala & Jala & Kata dasar \\
\hline 11 & Solu & Sampan & Kata dasar \\
\hline 12 & doran & $\begin{array}{l}\text { Pelampun } \\
\text { g jaring }\end{array}$ & Kata dasar \\
\hline
\end{tabular}

\begin{tabular}{|c|c|c|c|}
\hline 13 & Tahu tahu & $\begin{array}{l}\text { Alat timba } \\
\text { air untuk } \\
\text { di sampan }\end{array}$ & $\begin{array}{l}\text { Kata } \\
\text { Ulang }\end{array}$ \\
\hline 14 & Mangenet & $\begin{array}{l}\text { Menaikka } \\
\mathrm{n} \text { jaring ke } \\
\text { sampan }\end{array}$ & Verba \\
\hline 15 & Manggobuk & $\begin{array}{l}\text { Mengusir } \\
\text { ke jaring } \\
\text { mengunak } \\
\text { an alat } \\
\text { gobuk }\end{array}$ & Verba \\
\hline 16 & Mangarsik & $\begin{array}{l}\text { Mengelua } \\
\text { rkan air } \\
\text { dari } \\
\text { sampan } \\
\text { mengguna } \\
\text { kan tahu- } \\
\text { tahu }\end{array}$ & Verba \\
\hline 17 & Marsolu & $\begin{array}{l}\text { Menaiki } \\
\text { sampan }\end{array}$ & Verba \\
\hline 18 & Martelong & $\begin{array}{l}\text { Menemba } \\
\mathrm{k} \text { ikan } \\
\text { dengan } \\
\text { tombak } \\
\text { pada } \\
\text { malam } \\
\text { hari }\end{array}$ & Verba \\
\hline 19 & mangarisris & $\begin{array}{l}\text { Membersi } \\
\text { hkan } \\
\text { jaring dari } \\
\text { lumut }\end{array}$ & Verba \\
\hline 20 & manaon & $\begin{array}{l}\text { Memancin } \\
\text { g dengan } \\
\text { teknik } \\
\text { meninggal } \\
\text { kan kail }\end{array}$ & Verba \\
\hline
\end{tabular}

Berikut ini adalah beberapa gambar alat tangkap ikan yang digunakan di Danau Toba.

\section{Gambar 7}

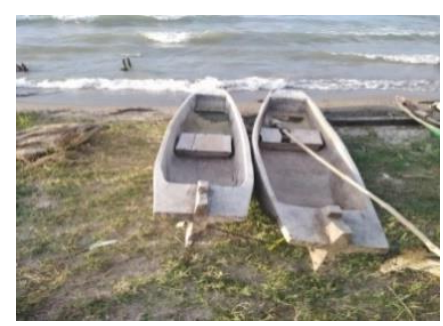

Solu

Sumber foto: Dokumentasi Johandi 2019 
Gambar 8

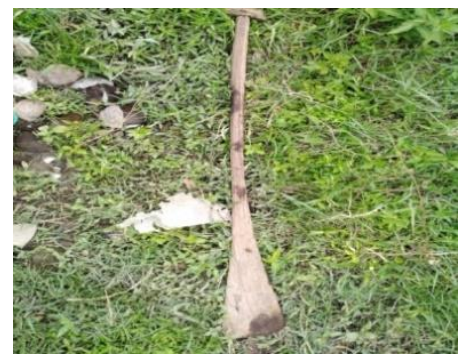

Hole

Sumber foto: Dokumentasi Johandi 2019

Gambar 9

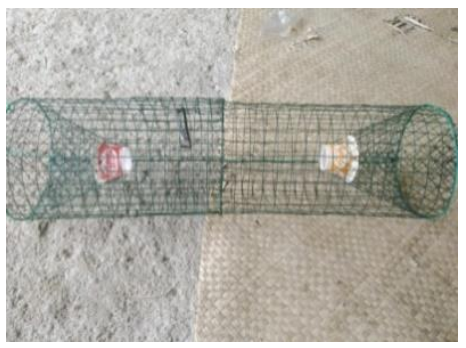

Bubu

Sumber foto: Dokumentasi Johandi 2019

\section{Gambar 10}

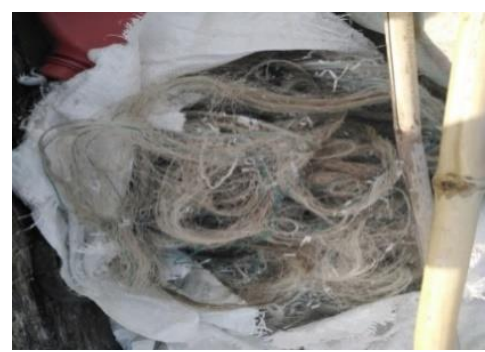

\section{Doton}

Sumber foto: Dokumentasi Johandi 2019

\section{Ekoleksikon Alat Tangkap Ikan}

Masyarakat yang tinggal di Kabupaten Samosir menggunakan beberapa alat untuk menangkap ikan. Penamaan alat tangkap ikan menggunakan bahasa daerah yaitu Batak Toba. Untuk menangkap ikan masyarakat mengenal leksikon solu 'perahu' untuk menangkap ikan. Solu merupakan perahu yang turun temurun sudah digunakan oleh masyarakat Batak Toba untuk mencari ikan. Di dalam solu ada bemacam-macam alat lain juga seperti doton yang terbuat dari bonang, Alat ini adalah jaring yang digunakan masyarakat untuk menangkap ikan dengan cara menebar di air menggunakan pemberat yang dikenal dengan leksikon holom. Holom terbuat dari besi dan berbentuk lingkaran. Supaya jaringnya tidak tenggelam doton juga menggunakan doran yang berfungsi sebagai pelambung yang terbuat dari busa padat dibentuk bulat.

Untuk menebar jaring, solu digerakkan menggunakan hole yang terbuat dari kayu pilihan seperti kayu ingul yang tahan lama di air. Proses menebar jaring ini dilakukan dalam posisi duduk. Di solu alat untuk duduk dikenal dengan leksikon goli-goli. Ketika jaring sudah ditebar di air untuk mengusir ikan ke arah jaring, masyarakat menggunakan alat bernama gobuk. Alat ini terbuat dari bambu, bentuknya panjang dan memiliki lobang di bagian bawahnya yang fungsinya membuat suara di air. Proses mengusir ikan mengarah ke jaring membuat air masuk ke dalam solu, untuk menimba air digunakan alat bernama tahu-tahu yang terbuat dari kayu atau bambu. Bentuk tahu-tahu seperti piring atau mangkuk. Hasil ikan tangkapan akan disimpan di dalam alat bernama $b u b u$ yang terbuat bambu atau kawat besi yang bentuknya lonjong. Ikan akan ditinggalkan di dalam bubu dan ditinggalkan dalam air untuk sementara, sampai hasil tangkapan cukup banyak untuk dibawa pulang.

Selain mengunakan solu untuk menangkap ikan, beberapa alat lain yang digunakan masyarakat untuk menangkap ikan dikenal dengan leksikon oddor. Alat ini terbuat dari mata kail dan talinya berupa tali pancing atau benang. Kemudian ada rambang yang terbuat dari benang tebal dan mempunyai pemberat mengguakan rantai, Alat ini biasanya digunakan di perairan yang dangkal. Selain itu ada alat bernama sidua tali, yang terbuat dari mata kail yang lebih dari satu di gantung pada satu benang kail yang sama. Alat ini akan dibuat memanjang dan penuh akan mata pancing. Ada juga alat jala, yang terbuat dari benang tebal dan rantai sebagai pemberat. Alat ini digunakan dari daratan yang dilemparkan membentuk lingkaran ke arah target yang diduga banyak ikan.

Pada ekoleksikon alat tangkap ikan ditemukan juga verba yaitu kegiatan yang dilakukan untuk menangkap ikan, diantaranya adalah mangenet, manggobuk, mangarsik, marsolu, martelong, mangarisris, manaon. 


\section{SIMPULAN}

Berdasarkan leksikon yang dikaji dalam penelitian ini, diperoleh simpulan penelitian sebagai berikut. dtiemukan tiga pembagian kategori entitas ekoleksikon. Adapun ketiga leksikon itu adalah ekoleksikon alat tangkap ikan, ekoleksikon flora, ekoleksikon fauna. Dari ketiga ekoleksikon ditemukan 29 leksikon. Bentuk-bentuk leksikon ada yang berbentuk dasar, bentuk turunan berupa kata ulang dan kata majenuk. Ditinjau dari kategori ditemukan kategori nomina dan veba.

\section{DAFTAR PUSTAKA}

Butar-Butar, C. (2017). Bahasa Kedanauan (Kajian Ekolinguistik Tentang Pelestari Ekosistem Danau Toba. USU Medan.

Chaer, A. (2008). Morfologi Bahasa Indonesia. Rineka Cipta.

Fill, A. dan peter M. (2001). The Ecolinguistics
Reader Language, Ecology, Enviroment (2nd ed.). Continum.

Mbete, A. M. (2009). Selayang Pandang Tentang Ekolinguistik: Perspektif Kelinguistikan Yang Prospektif”'. (Bahan Untuk Berbagi Pengalaman Kelinguistikan Dalam Martikulasi.

Sudaryanto. (2015). Metode dan Teknik Analisis Bahasa. Sanata Dharma University Press.

Sudaryanto. (2017). Menguak Tiga Faset Kehidupan Bahasa. Sanata Dharma University Press.

Sukhrani, D. (2010). Leksikon Nomina Bahasa Gayo dalam Lingkungan Kedanauan Lut Tawar: Kajian Ekolinguistik. USU Medan.

Verhaar. J. W. M. (2008). Asas-asas Linguistik. Gadjah Mada University Press. 